\title{
O papel das políticas territoriais especiais para a transformação das cidades de zona de fronteira: o caso das cidades gêmeas de Brasileia, Epitaciolândia e Cobija
}

\begin{abstract}
Resumo
As zonas de fronteira possuem importante valor estratégico para os Estados. Tal valor centra-se na sua importância no âmbito da segurança e da cooperação. Como um movimento para a valorização das zonas de fronteira, os Estados têm criado políticas territoriais especiais que beneficiam o desenvolvimento e o dinamismo regional. $\mathrm{O}$ artigo apresentará um estudo que contou com a realização de um trabalho de campo às cidades gêmeas de Brasiléia, Epitaciolândia e Cobija e que teve como intuito a percepção da alteração da realidade geográfica promovida pelas políticas de fronteira. $O$ trabalho contou com o levantamento de dados das redes econômicas, hoteleiras e educacionais das cidades investigadas.
\end{abstract}

Palavras-Chave: Faixa de Fronteira. Cidades Gêmeas. Políticas territoriais.

The role of special territorial policy to the transformation of the border area cities: the case of the twin cities of Brasileia, Epitaciolândia and Cobija

\begin{abstract}
The border areas have important strategic value to the countries. This value focuses on its importance in the field of security and cooperation. As a move to the appreciation of the border zone, the countries have created special territorial policies that benefit the development and regional dynamism. The article will present a study that included a field work to the twin cities of Brasiléia, Epitaciolândia and Cobija as a method and had the intention to perceive the change of the geographical reality promoted by border policies. This paper included data of the economic, hotel and educational networks of the studied cities.
\end{abstract}

Keywords: Border Strip. Twin Cities. territorial policies. 


\section{Introdução}

O presente artigo trata de um recorte temático de uma tese defendida no programa de pós Graduação de Geografia da PUC-Minas em 2016. A partir deste recorte, a discussão sobre as políticas territoriais voltadas para a zona de fronteira será aprofundada. A estratégica região de fronteira, entendida como um espaço de cooperação e segurança, tem sido alvo de políticas territoriais especiais que contribuem para a transformação das regiões que as abrigam. $\mathrm{O}$ artigo em questão propõe a reflexão sobre as transformações espaciais provocadas por tais políticas na periferia territorial do Brasil e na Bolívia, países que criam espaços de exceção nestas áreas estratégicas. $O$ estudo é direcionado pontualmente para as áreas urbanas das cidades gêmeas de Brasileia, Epitaciolândia (situadas no Acre) e Cobija (situada no departamento boliviano de Pando).

A hipótese deste trabalho parte do pressuposto de que as políticas territoriais especiais são capazes de dinamizar e rearranjar dramaticamente o status quo econômico dos espaços por elas contemplados. O presente estudo não pretende dimensionar toda a extensão das transformações econômicas regionais, restringindo-se, portanto, àquelas facilmente correlacionadas aos termos dos textos das leis que impõem sobre as regiões estudadas condições territoriais especiais. Para tanto, baseia-se no método dedutivo.

Quanto à sua estrutura, o artigo apresentará primeiramente uma breve discussão sobre os limites e fronteiras e sobre as cidades gêmeas. Posteriormente, apresentará as políticas territoriais do Brasil e da Bolívia para as áreas de fronteira. Finalmente, avaliará algumas das notáveis modificações espaciais das cidades contempladas pelas políticas territoriais especiais. Tal avaliação ocorrerá a partir das impressões e dados colhidos em um trabalho de campo realizado em janeiro de 2015.

\section{Limites e Fronteiras}

Quando se imagina a realidade territorial dos Estados modernos, considera-se que limite é a linha natural ou artificial que contorna o extremo do território físico do Estado. Para Lia Osório Machado (2000), o limite jurídico do território é uma abstração, gerada e sustentada pela ação institucional no sentido do controle efetivo do Estado territorial, portanto, um instrumento de separação entre unidades políticas e soberanas. Já a fronteira é a faixa contígua à linha do limite. Usualmente, os Estados estabelecem a extensão dessa faixa, fato que restringe o universo semântico do termo, estreitando as brechas para as interpretações subjetivas.

Existe uma confusão relativamente comum acerca da diferença entre os conceitos de fronteira e faixa de fronteira. A primeira, possui definição informal, enquanto a segunda, possui uma definição jurídico/ administrativa. A faixa de fronteira pode ser entendida como uma realidade concreta. Não há subjetividade nesse conceito, pois se refere 
a uma área convencionada estabelecida por países ou outras formas de organização política segundo as normas do direito internacional, leis e constituições dos envolvidos (ABINZANO, 2005). Entre os países, existem diferenças na definição dessas faixas fronteiriças, que acabam por ser estabelecidas por lei e submetidas a algum tipo de regulamentação específica, conforme os interesses do Estado que nela exerce a soberania. Para o Brasil, a sua dimensão é assim definida pela Constituição Federal:

a faixa de até $150 \mathrm{~km}$ de largura, ao longo das fronteiras terrestres, designada como faixa de fronteira, é considerada fundamental para a defesa do território nacional e sua ocupação e utilização serão regulamentadas por lei. (BRASIL, Cap.II, Art.20, alínea XI, parágrafo II, 1988).

Já para a Bolívia, a extensão da faixa de fronteira é três vezes menor do que a brasileira. Nessa faixa, a Bolívia tem feito um esforço para evitar a presença de estrangeiros como proprietários de terras, movimento que se acentuou no governo de Evo Morales. Assim diz o trecho da Constituição Boliviana sobre o assunto:

constitui-se zona de segurança de fronteira os cinquenta quilômetros a partir da linha da fronteira. Nenhuma pessoa estrangeira, individualmente ou em sociedade, poderá adquirir propriedade neste espaço, direta ou indiretamente, nem possuir nenhum título de propriedade de água, solo ou subsolo. A propriedade ou a posse afetada em caso de descumprimento desta proibição passarão ao benefício do Estado sem nenhuma indenização. A lei poderá prever exceções a esta proibição (BOLÍVIA, Art. 261, linha I, 2009).

A extensão que envolve a soma territorial de duas faixas de fronteira adjacentes é chamada de Zona de Fronteira (MACHADO, et. al.,2005). Desse modo, a Zona de Fronteira boliviano-brasileira possui 200 $\mathrm{km}$ de extensão. Por outro lado, a definição de fronteira é mais frouxa, podendo ser aplicada às diversas realidades: fala-se de fronteiras entre as jurisdições regionais, províncias, estados e municípios; nestes casos de divisões internas, normalmente o conceito de fronteira se confunde com o de limite (MATTOS, 1990). Sendo uma região periférica, a fronteira é a faixa de contato com outras soberanias, com o mar ou com o espaço aéreo cujos limites jurisdicionais e direito de utilização são regulados por leis internacionais. Por isso, trata-se de uma região sensível, onde os direitos soberanos dos Estados se contatam fisicamente (MATTOS, 1990). Enquanto a fronteira é considerada uma fonte de perigo ou ameaça porque pode desenvolver interesses distintos aos do governo central, o limite jurídico do Estado é criado e mantido pelo governo, não possuindo vida própria e se tratando de um polígono (MACHADO, 1998).

As fronteiras terrestres são as de questionamento mais antigo, por isso mesmo, encontra-se bastante consolidado o direito internacional que regula o seu traçado e a sua funcionalidade. A aceitação de uma linha de limites pelos países confinantes, seja natural ou artificial, não deve dispensar a necessidade de sua demarcação física. Quando se trata de fronteiras naturais, tais como rios, lagos, montanhas, cordilheiras ou desertos, há várias regras de demarcação já consagradas por critérios internacionais (MATTOS, 1990). Boa parte do limite entre o Brasil e a Bolívia é definido pelo contorno fluvial, inclusive o trecho em que estão inseridas as cidades brasileiras de Brasiléia e Epitaciolândia e a cidade boliviana de Cobija', alvos deste artigo científico. 
Figura 1. Rio Acre: limite natural entre Brasiléia (Brasil) e Cobija (Bolívia)

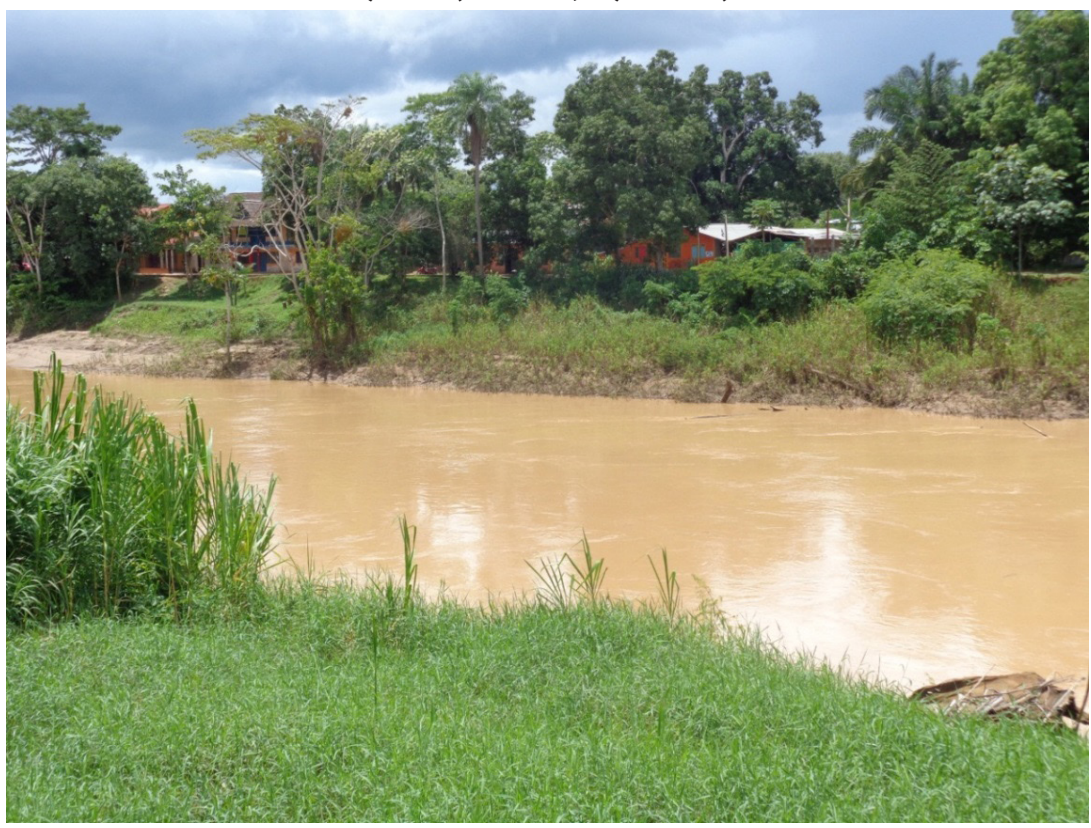

Fonte: Foto do autor

Cássio Eduardo Viana Hissa, no livro A mobilidade das fronteiras, traz uma reflexão epistemológica acerca dos conceitos de fronteiras e limites. Segundo Hissa (2002), fronteiras e limites fornecem imagens conceituais equivalentes. Contudo, o autor desenvolve as diferenciações nos conceitos ao considerar que

(...) o limite está voltado para dentro, enquanto a fronteira, imaginada do mesmo lugar, está voltada para fora, como se pretendesse a expansão daquilo que lhe deu origem (...).

(...) O limite estimula a ideia sobre a distância e a separação, enquanto a fronteira movimenta a reflexão sobre contato e a integração (...)

(...) O limite almeja a precisão e se insinua como muro, mas, contraditoriamente, por estar contido na fronteira e através dela, apresentase também como uma transição (HISSA, 2002, p.35).

Uma reflexão sobre limites e fronteiras é também uma reflexão sobre o poder (HISSA, 2002). As oscilações espaciais dos limites e das fronteiras após a expansão da ideia do Estado moderno pós-vestfaliano foram notáveis e revelam as mudanças nas relações de poder que se manifestam no espaço em diferentes escalas e exercidas por diversos atores. A fronteira é um lugar de comunicação e troca. Os povos podem se expandir para além do limite jurídico do estado, desafiar a lei territorial de cada Estado limítrofe e, às vezes, criar uma situação de facto, potencialmente conflituosa, obrigando a revisão dos acordos diplomáticos (MACHADO, 2000). É justamente o papel estratégico da fronteira que motiva a mesma ser tratada em parte da literatura como sinônimo de limite, como esclarece Lia Osório Machado:

não é surpresa, portanto, que a fronteira, historicamente, tem sido objeto permanente de preocupação dos Estados, no sentido de controle e vínculo. Tampouco é surpreendente que um dos objetivos do sistema histórico de Estados Nacionais, em vigência por quase dois séculos, foi o de estimular a coincidência entre limite e fronteira, disso resultando uma convergência conceitual, a ponto de serem consideradas na literatura como sinônimos. (MACHADO, 2000, p.10).
1 O limite entre Brasiléia e Cobija é definido pelo contorno do rio Acre. Já o limite entre Epitaciolândia e Cobija é definido por um igarapé de pequeno volume. 
A mesma autora argumenta que a convergência conceitual entre limites e fronteiras deve ser revista frente aos novos agenciamentos do poder político e econômico e do espaço físico mundial. As principais manifestações dessas mudanças têm sido, de um lado, os agrupamentos funcionais de Estados (expressos através dos blocos econômicos internacionais), a proliferação de organizações internacionais e transnacionais e as migrações internacionais"; de outro lado, "as formas de organização em rede, possibilitadas pela revolução tecnológica dos meios de comunicação e informacionais, rápidos em redefinir espaços de transação não coincidentes com o espaço territorial dos Estados nacionais" (MACHADO, 2000, p.10). É por causa dessa segunda manifestação que a mensuração dos fluxos transnacionais é fator precípuo para atestar a soberania em risco, sobretudo em áreas limítrofes. Considerando que rede, território e poder são conceitos entremeados, é plausível admitir que as nações mais poderosas "são capazes, às vezes, de instrumentalizar os fluxos transnacionais e de melhorar o seu ascendente sobre os mais fracos" (BADIE, 1995, p.206). O desarranjo das redes transnacionais em relação aos limites Estatais se explica em boa parte pelo uso que os próprios estados fazem de sua soberania.

A transnacionalidade do arranjo das redes contribui para o entendimento da ascensão de atores que diluem a soberania Estatal. Assim, a intensificação da difusão, da diversidade e da densidade das redes contribui para reforçarmos a crença de que uma abordagem meramente pautada na soberania e na exclusão de atores não estatais no jogo político internacional é insuficiente para o fazer geopolítico contemporâneo.

\section{Cidades Gêmeas}

Como foi apresentado na introdução, as três cidades alvo desta pesquisa são cidades gêmeas, situadas na periferia territorial do Brasil (Brasiléia e Epitaciolândia) e da Bolívia (Cobija) ainda que esta última seja uma capital departamental. Os Mapas 1 e 2 a seguir destacam sua posição geográfica em diferentes escalas.

As cidades gêmeas são espaços conurbados transfronteiriços que envolvem duas ou mais cidades. Formam por meio da conurbação uma região híbrida composta por elementos nacionais e internacionais, guardando para si uma identidade local única (COELHO, 2013; TERENCIANI, 2012). A unicidade de suas características surge na literatura como um desafio para a elaboração de uma legislação que seja adequada às demandas locais. Silva e Oliveira (2008) destacam que se trata de uma estratégia de grande parte dos pesquisadores de fronteira concentrar os seus estudos nas cidades gêmeas, onde melhor são esboçadas as interações das sociedades transfronteiriças. Nas cidades gêmeas, as assimetrias e simetrias entre sistemas territoriais nacionais e internacionais são mais visíveis, o que reforça o seu papel de alicerce da cooperação entre os países vizinhos (MACHADO et. al., 2005). As cidades gêmeas destacam-se como importantes nós de concentração e dispersão dos fluxos de diversas redes transnacionais.
2 Eventos que reforçam as argumentações de Bertrand Badie (1999) no livro "Um mundo sem soberania”, em que o autor francês aborda o papel da globalização para a crise da soberania moderna. Um Estado que atravessa a crise de soberania obviamente coloca em risco seus limites territoriais e sua fronteira, enfrentando o processo da desterritorialização nas dimensões econômica, política e cultural, tais como foram trabalhadas por Rogério Haesbaert (2004) no livro "O mito da desterritorialização". 
Mapa 1. Posição Geográfica da conurbação Brasileia-Epitaciolândia-

Cobija em escala continental

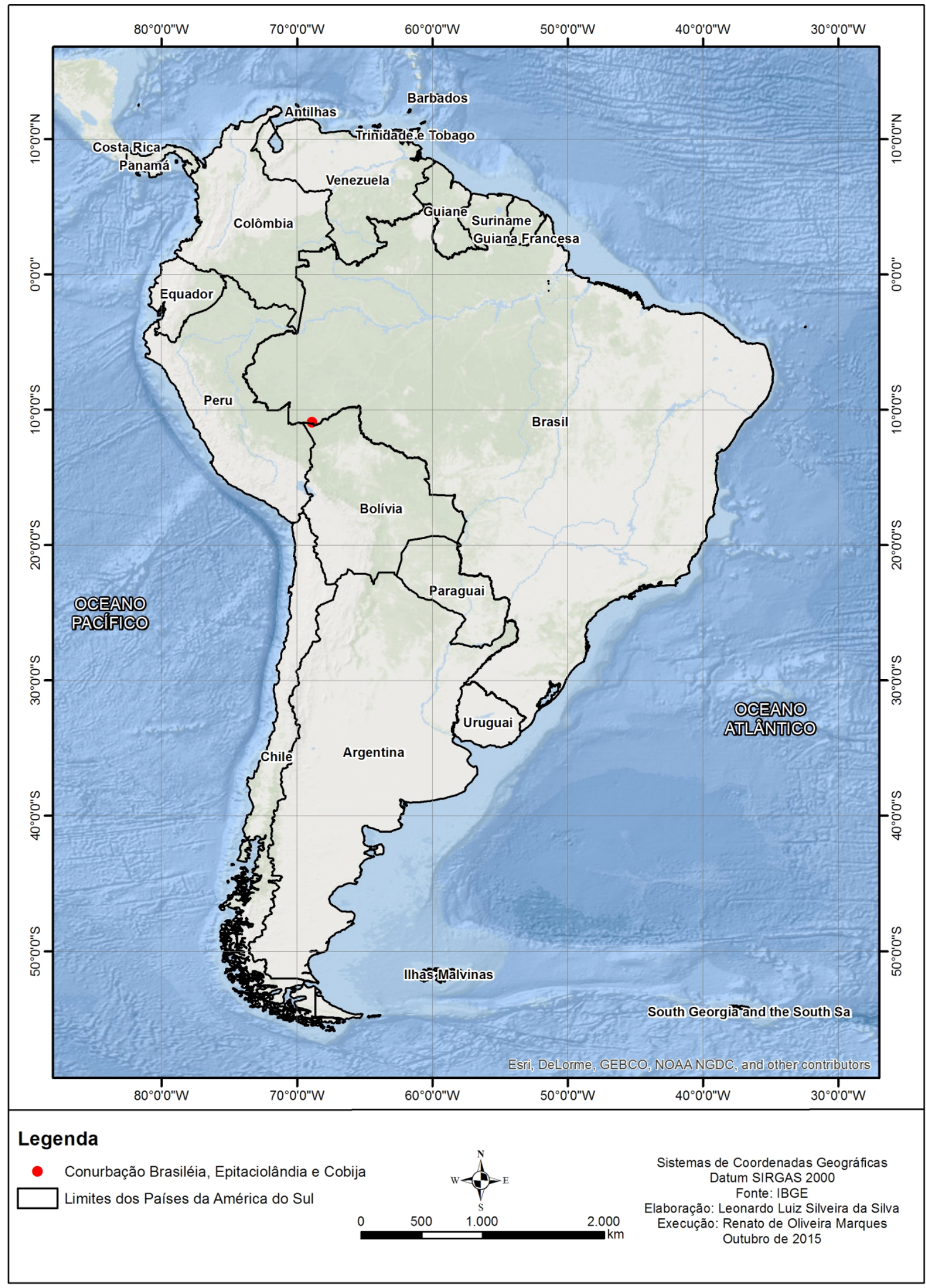


O papel das políticas territoriais especiais para a transformação das cidades de zona de fronteira: o caso das cidades gêmeas de Brasileia, Epitaciolândia e Cobija

Mapa 2. Arruamento básico da conurbação Brasiléia-Epitaciolândia-Cobija

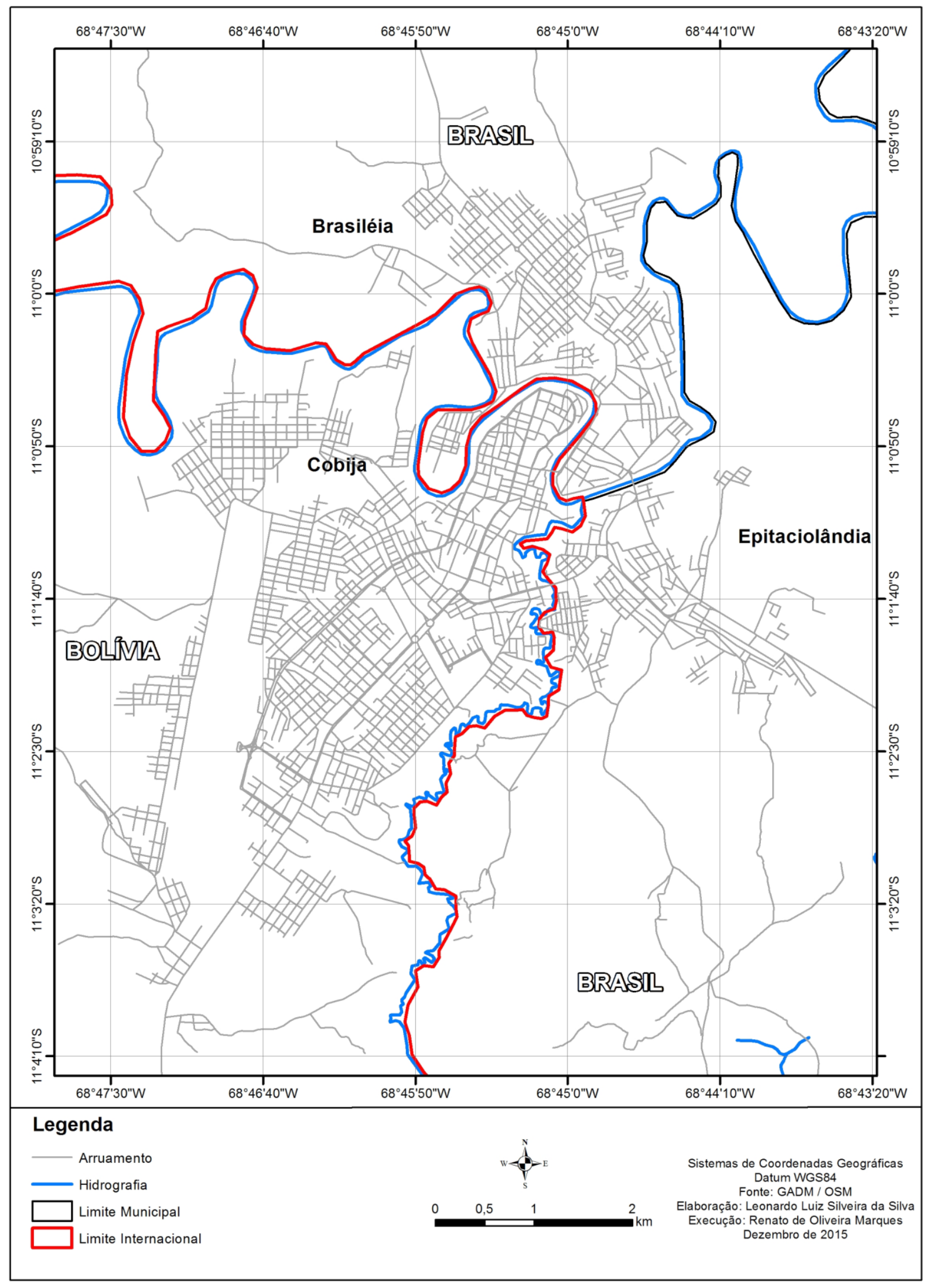




\title{
4 Políticas territoriais de fronteiras brasileiras
}

A possibilidade de barganhar a soberania pode fazer parte de uma escolha do Estado, como argumenta Bertrand Badie (1999). As novas formas de comunicação e transporte que se apresentam não servem somente ao exercício das atividades político-econômicas do Estado, como também são apropriadas por redes criminosas. A circulação informal, nessa lógica, é reforçada em detrimento da circulação regulada por lei (MACHADO, 1998). O arranjo dessas redes criminosas desafia a soberania Estatal sem o consentimento do Estado, consolidando-se como uma das principais preocupações na Zona de Fronteira, que enfrenta o papel ambíguo de servir a segurança e à integração. Mediante a este cenário, o Estado moderno reage a fluidez informal:

\begin{abstract}
Apresenta-se como uma reação às ameaças contemporâneas à soberania uma tendência para a proliferação de leis, normas e regras no interior dos territórios nacionais, válidos para certos setores e lugares, mas não para outros. Na geografia do sistema mundial de Estados nacionais se observa algo similar com a formação de "territórios-objetos, isto é, territórios desenhados para atingir objetivos específicos, que servem como expediente legal para as ações consideradas ilegais no país de origem (paraísos fiscais, centros financeiros offshore)". (MACHADO, 2000, p.11).
\end{abstract}

Alinhado com a perspectiva trazida por Lia Osório Machado (2000), o Estado brasileiro vem desenvolvendo zonas especiais nas áreas de fronteiras no intuito de garantir a sua soberania e estimular a cooperação. Tanto o Sistema de Vigilância da Amazônia-SIVAM quanto o projeto Calha Norte aludem à preocupação do governo federal com as fronteiras subpovoadas da Amazônia brasileira. De forma notável, destaca-se como outra iniciativa, o Programa de Desenvolvimento da Faixa de Fronteira-PDFF. A sua existência é justificada a partir do segundo argumento:

\footnotetext{
a preocupação com a segurança nacional, de onde emana a criação de um território especial ao longo do limite internacional continental do país, embora legítima, não tem sido acompanhada de uma política pública sistemática que atenda às especificidades regionais, nem do ponto de vista econômico nem da cidadania fronteiriça. Motivos para isso não faltaram até o passado recente, como a baixa densidade demográfica, a vocação "atlântica" do país, as grandes distâncias e as dificuldades de comunicação com os principais centros decisórios, entre outros. (BRASIL, 2005, p.9).
}

O documento do governo federal destaca ainda que existem novas condicionantes que mobilizam a ação governamental na faixa de fronteira. Essas condicionantes são agrupadas em cinco diferentes níveis, que são, na verdade, escalas geográficas, dispostas no Quadro 1. 
Quadro 1. Novas condicionantes que norteiam as diretrizes do PDFF

\begin{tabular}{|c|c|}
\hline $\begin{array}{l}\text { Escala das Novas } \\
\text { Condicionantes }\end{array}$ & Condicionantes \\
\hline \multirow[t]{3}{*}{ Global } & $\begin{array}{l}\text { Mudança das condições técnico-tecnológicas (sistema } \\
\text { global de telecomunicações) no campo da produção e } \\
\text { troca de informações possibilitando o acesso dos povos } \\
\text { da fronteira a centros de poder que não só o do Estado } \\
\text { Nacional a que pertencem. }\end{array}$ \\
\hline & $\begin{array}{l}\text { Proliferação de estratégias e planos de ação de organismos } \\
\text { internacionais e empresas transnacionais, interferindo na } \\
\text { pauta e nos meios disponíveis dos governos nacionais. }\end{array}$ \\
\hline & $\begin{array}{l}\text { Pressões internacionais sobre questões especificas } \\
\text { (indígenas, ecologia, tráfico de ilícitos) que não estão } \\
\text { cobertas pelos atuais sistemas de controle territorial dos } \\
\text { Estados Nacionais. }\end{array}$ \\
\hline \multirow[t]{4}{*}{ Subcontinental } & $\begin{array}{l}\text { Implantação e desenvolvimento de agrupamentos } \\
\text { funcionais dos estados-nações (MERCOSUL, Comunidade } \\
\text { Andina), possibilitando a formulação de novo marco } \\
\text { regulatório das interações entre os Estados, inclusive } \\
\text { a criação de territórios especiais regido por normas } \\
\text { bilaterais ou multilaterais. }\end{array}$ \\
\hline & $\begin{array}{l}\text { Esforço, ainda em marcha lenta, de integração da malha } \\
\text { rodoviária por parte de vários governos sul-americanos } \\
\text { com objetivo de conectar a vertente do Atlântico à } \\
\text { vertente do Pacífico. }\end{array}$ \\
\hline & $\begin{array}{l}\text { Problema da intensificação do tráfico de armas e drogas } \\
\text { ilícitas na Zona de Fronteira, com efeitos sobre os } \\
\text { condicionantes do desenvolvimento econômico e social } \\
\text { nas regiões subnacionais. }\end{array}$ \\
\hline & $\begin{array}{l}\text { Expansão de movimentos migratórios e pendulares na Zona } \\
\text { de Fronteira que exigem tratamento bilateral ou multilateral. }\end{array}$ \\
\hline \multirow{4}{*}{ Nacional } & $\begin{array}{l}\text { Ajuste das políticas públicas estatais à "permeabilidade" } \\
\text { das fronteiras. }\end{array}$ \\
\hline & $\begin{array}{l}\text { Integração da Faixa de Fronteira às outras regiões do } \\
\text { país por estar à frente do processo de integração sul- } \\
\text { americana. }\end{array}$ \\
\hline & $\begin{array}{l}\text { Promover a cidadania e o desenvolvimento regional } \\
\text { como forma de combater o crescimento de diversos tipos } \\
\text { de tráfico de ilícitos. }\end{array}$ \\
\hline & $\begin{array}{l}\text { Criar novos espaços de articulação entre os sistemas } \\
\text { territoriais produtivos de áreas com povoamento } \\
\text { consolidado e não-consolidado do país. }\end{array}$ \\
\hline \multirow[t]{2}{*}{ Subnacional } & $\begin{array}{l}\text { Sinais de insatisfação com o modelo tradicional de } \\
\text { relações hierárquicas entre o estado/região (inferior) e } \\
\text { o centro decisório nacional (superior), que na Faixa de } \\
\text { Fronteira se expressa pela crítica ao desconhecimento } \\
\text { dos efeitos na escala subnacional e local de decisões } \\
\text { tomadas na esfera federal. }\end{array}$ \\
\hline & $\begin{array}{l}\text { Iniciativas dos estados federados em criar laços } \\
\text { comerciais e culturais diretamente com o mercado global, } \\
\text { obedecendo a pressões e estratégias de cunho regional, } \\
\text { mas que são débeis e pouco articuladas quando se } \\
\text { referem aos países vizinhos. }\end{array}$ \\
\hline Local & $\begin{array}{l}\text { Demanda por maior conhecimento do centro decisório } \\
\text { nacional sobre as especificidades territoriais dos } \\
\text { municípios de fronteira. }\end{array}$ \\
\hline
\end{tabular}

Fonte: BRASIL, 2005. 
Mesmo sendo condicionantes que são apresentadas em escalas geográficas diferentes, trata-se de temas muito caros para a conurbação Brasileia/Epitaciolândia/Cobija. Tais condicionantes são pertencentes a dimensões distintas, sendo, portanto, difícil de serem hierarquizadas. O PDFF é grandioso em diversos aspectos. Ao todo são 588 municípios da faixa de fronteira brasileira contemplados. Tais municípios apresentam situação geográfica distinta em relação à linha de fronteira ${ }^{3}$, como consta no Quadro 2.

Quadro 2. Características dos municípios contemplados pela PDFF

\begin{tabular}{|c|l|}
\hline $\begin{array}{c}\text { Tipo de Município } \\
\text { contemplado pela PDFF }\end{array}$ & \multicolumn{1}{|c|}{ Característica } \\
\hline \multirow{6}{*}{ Lindeiro } & $\begin{array}{l}\text { O território do município faz limite com o país } \\
\text { vizinho e sua sede se localiza no limite internacional, } \\
\text { podendo ou não apresentar uma conurbação ou } \\
\text { semiconurbação com uma localidade do país vizinho } \\
\text { (cidades gêmeas). }\end{array}$ \\
\cline { 2 - 3 } & $\begin{array}{l}\text { O território do município faz divisa com o país } \\
\text { vizinho, mas cuja sede não se situa no limite } \\
\text { internacional. }\end{array}$ \\
\cline { 2 - 3 } & $\begin{array}{l}\text { O território do município faz divisa com o país } \\
\text { vizinho, mas cuja sede está fora da Faixa de } \\
\text { Fronteira. }\end{array}$ \\
\hline \multirow{5}{*}{ Não Lindeiro } & $\begin{array}{l}\text { O município não faz divisa com o país vizinho e a } \\
\text { sua sede situa-se dentro da faixa de fronteira. }\end{array}$ \\
\cline { 2 - 3 } & $\begin{array}{l}\text { O município não faz divisa com o país vizinho, } \\
\text { possui apenas parte do seu território inserido na } \\
\text { fora da faixa em questão. }\end{array}$ \\
\hline
\end{tabular}

Fonte: BRASIL, 2005, organizado pelo autor.

\begin{abstract}
A grande extensão territorial da Faixa de Fronteira brasileira concomitantemente aos diferentes sensos de territorialidade, distribuição e densidade dos meios de territorialização ${ }^{4}$ motivaram a regionalização da faixa de fronteira
brasileira, que foi dividida em três grandes regiões e diversas subterritorialização ${ }^{4}$ motivaram a regionalização da faixa de fronteira
brasileira, que foi dividida em três grandes regiões e diversas subregiões, conforme o Quadro 3 a seguir:
\end{abstract}

3 Linha que estabelece o limite da faixa de fronteira definido pela lei brasileira (150 km de extensão a partir do limite do território nacional).

4 São entendidos como meios de territorialização as estradas, a ocupação econômica do espaço, o adensamento populacional, a presença de cidades e a atuação dos órgãos públicos. 
O papel das políticas territoriais especiais para a transformação das cidades de zona de fronteira: o caso das cidades gêmeas de Brasileia, Epitaciolândia e Cobija

Quadro 3- Regiões e suas respectivas Sub-Regiões estabelecidas pelo PDFF

\begin{tabular}{|c|c|}
\hline Região & Sub-região \\
\hline \multirow{6}{*}{ Arco Norte } & Oiapoque-Tumucumaque \\
\hline & Campos do Rio Branco \\
\hline & Parima-Alto Rio Negro \\
\hline & Alto Solimões \\
\hline & Alto Juruá \\
\hline & Vale do Acre-Alto Purus \\
\hline \multirow{8}{*}{ Arco Central } & Madeira-Mamoré \\
\hline & Fronteira do Guaporé \\
\hline & Chapada dos Parecis \\
\hline & Alto Paraguai \\
\hline & Pantanal \\
\hline & Bodoquena \\
\hline & Dourados \\
\hline & Cone Sul Matogrossense \\
\hline \multirow{3}{*}{ Arco Sul } & Portal do Paraná \\
\hline & Vales Coloniais Sulinos \\
\hline & $\begin{array}{l}\text { Fronteira da Metade Sul do Rio Grande do } \\
\text { Sul }\end{array}$ \\
\hline
\end{tabular}

Fonte: BRASIL, 2005, organizado pelo autor.

O PDFF tem como objetivo principal promover o desenvolvimento da Faixa de Fronteira, por meio de sua estruturação física, social e produtiva, com ênfase na ativação das potencialidades locais e na articulação com outros países da América do Sul (BRASIL, 2009). Há uma crença dos gestores do programa de que os atores locais, uma vez fortalecidos, vão protagonizar "o processo de desenvolvimento endógeno e sustentável, resultando no fortalecimento de novos eixos dinâmicos da economia" (BRASIL, 2009, p.14). Compõem as diretrizes do PDFF:

A) Fortalecimento Institucional: refere-se a diversas ações que visam à participação público-privada no processo decisório de gestão das demandas das áreas de fronteira, bem como o estímulo para a participação de atores transnacionais;

B) Desenvolvimento econômico integrado: refere-se a incentivos diversos no investimento em infraestrutura facilitadora do desenvolvimento econômico, bem como um esforço tarifário para a redução de custos da telefonia em área de fronteira;

C) Condições de Cidadania: diz respeito ao desenvolvimento de programas de defesa de direitos humanos, do incentivo à preservação da cultura e ao exercício pleno da cidadania;

D) Marco Regulatório/Legal: diz respeito ao esforço para o desenvolvimento de um estatuto geral para a zona de fronteira e, caso a caso, de acordo com o que se estabelece com cada país vizinho, estatutos mais detalhados para relações bilaterais (BRASIL, 2009). 


\section{Áreas de Livre Comércio Brasileiras}

Concomitante à ação brasileira do PDFF, estão as Áreas de Livre Comércio-ALCs. Tais áreas foram criadas para promover o desenvolvimento das cidades de fronteiras internacionais localizadas na Amazônia Ocidental e em Macapá e Santana, com o intuito de integrá-las ao país (SUFRAMA, 2013). No sentido prático, oferecem benefícios fiscais semelhantes aos da Zona Franca de Manaus no aspecto comercial. Os incentivos concentram-se na isenção do Imposto Sobre Produtos Industrializados-IPI e do Imposto Sobre Circulação de Mercadorias e Prestação de Serviços-ICMS.

Quadro 4. Cidades contempladas pelo regime das ALCS

\begin{tabular}{|c|c|c|}
\hline Cidade & Unidade da Federação & Cidade-Gêmea \\
\hline Boa Vista & Roraima & Não \\
\hline Bonfim & Roraima & Sim \\
\hline Guajará-Mirim & Rondônia & Sim \\
\hline Brasiléia & Acre & Sim \\
\hline Epitaciolândia & Acre & Sim \\
\hline Cruzeiro do Sul & Acre & Não \\
\hline Tabatinga & Amazonas & Sim \\
\hline Macapá & Amapá & Não \\
\hline Santana & Amapá & Não \\
\hline
\end{tabular}

Fonte: SUFRAMA, 2013.

Como informa a tabela, nem todas as cidades de fronteira contempladas pelo regime das ALCs se enquadram na categoria de cidades gêmeas. Ainda assim, devido à relevância estratégica da área de fronteira, recebem o incentivo fiscal, possibilitando que o preço de inúmeros produtos industrializados seja mais competitivo. Sem o incentivo, a zona fronteiriça brasileira, sobretudo no grande arco que envolve a Região Norte brasileira, pode melhor se associar às redes transfronteiriças do que ao conjunto do espaço nacional, fragilizando assim o exercício do poder do Estado sobre aquela porção territorial estratégica. A competitividade da produção nacional nas áreas distantes dos parques industriais brasileiros é realçada por meio das políticas de incentivos fiscais. Senhoras (2013) destaca que um dos principais objetivos da criação das ALCs é a promoção do desenvolvimento das cidades amazônicas localizadas na faixa de fronteira. Isso se dá em razão dos vazamentos de renda de brasileiros que facilmente têm trânsito de compra nas cidades fronteiriças dos países vizinhos (Guiana, Venezuela, Colômbia, Peru e Bolívia).

As cidades de fronteira, assim como qualquer núcleo urbano, são, em alguma medida, eixos articuladores das relações que se dispõem sobre o território no qual estão inseridas. Ao examinar o papel das cidades na contemporaneidade, Ash Amin (2002) escreve que as cidades não podem ser vistas como unidades territoriais restritas, mas pelas múltiplas relações que por elas são engendradas. Pensando nesse sentido, os incentivos fiscais que atuam nas cidades localizadas no 
espaço fronteiriço buscam realçar o papel de articulação dos fluxos das redes que se dispõem no território, fazendo delas um posto avançado de territorialização do espaço nacional. As cidades gêmeas da Região Norte são alvos preferenciais das políticas de incentivo do governo, dado a forte atuação das redes transfronteiriças sobre o seu espaço. Sobre as estratégias de gestão territorial dos espaços transfronteiriços, destaca Senhoras (2013):

\begin{abstract}
registra-se em um primeiro momento a difusão sistêmica de uma lógica geopolítica baseada em regimes de contenção fronteiriça, por meio de zonas ou faixas de segurança, buscando não somente instrumentalizar a limitação entre o interno e o externo, mas principalmente territorializar as fronteiras por meio da constituição das cidades. Em momento posterior, a lógica desenvolvida é essencialmente geoeconômica, embora também fundamentada em estímulos geopolíticos e geoculturais, passando a fomentar a formação sócio-espacial de cidades gêmeas fronteiriças e a normatização de regimes aduaneiros em áreas especiais, como é o caso das Áreas de Livre Comércio, na Amazônia, dos Portos Livres, e das Zonas de Processamento de Exportação (ZPE) (SENHORAS, 2013, p.5)
\end{abstract}

\title{
A Área de Livre Comércio de Brasiléia e Epitaciolândia
}

A lei $n^{\circ} 8.857$ de 8 de março de 1994 determinou a criação das ALCs de Brasiléia, Epitaciolândia e Cruzeiro do Sul. Apesar das ALCs em questão ainda não estarem implantadas, as empresas cadastradas na Supeintendência da Zona Franca de Manaus-SUFRAMA nessas localidades usufruem regularmente dos benefícios fiscais inerentes ao IPI, sendo que as mercadorias são obrigatoriamente desembaraçadas nas Coordenações Regionais de Cruzeiro do Sul e Rio Branco/AC (SUFRAMA, 2013). Contudo, a não implementação impede que os comerciantes possam importar utilizando os benefícios fiscais previstos para as ALCs no texto da lei. Como Brasiléia e Epitaciolândia são municípios conurbados, ficou definido que a Área de Livre Comércio de Brasileia e Epitaciolândia-ALCBE abrangerá as duas cidades, apesar do escritório da SUFRAMA estar situado em Brasiléia. Já a ALC de Cruzeiro do Sul-ALCCS é autônoma. As condições legais que envolvem o funcionamento da ALCBE e da ALCCS são as mesmas. Assim diz o texto da lei quanto à entrada de mercadorias estrangeiras nas referidas ALCs:

\footnotetext{
Art. $4^{\circ} \mathrm{A}$ entrada de mercadorias estrangeiras nas Áreas de Livre Comércio de Brasiléia - ALCB e de Cruzeiro do Sul - ALCCS far-se-á com a suspensão do Imposto de Importação e do Imposto sobre Produtos Industrializados, que será convertida em isenção quando as mercadorias forem destinadas a:

I - consumo e vendas internas nas Áreas de Livre Comércio de Brasiléia - ALCB e de Cruzeiro do Sul - ALCCS;

II - beneficiamento, em seus territórios, de pescado, pecuária, recursos minerais e matérias-primas de origem agrícola ou florestal;

III - agropecuária e piscicultura;

IV - instalação e operação de turismo e serviços de qualquer natureza;

$\checkmark$ - estocagem para comercialização no mercado externo;

VI - industrialização de produtos em seus territórios;

VII - bagagem acompanhada de viajantes, observados os limites fixados pelo Poder Executivo por intermédio da Secretaria da Receita Federal. (BRASIL, CONSTITUIÇÂO FEDERAL, lei 8.857, 1994).
}

Alguns tipos de produtos estrangeiros não serão beneficiados pelo regime de isenção fiscal, destacando-se dentro destes tipos as bebidas alcóolicas, armas e munições, fumos e derivados, automóveis 
de passageiros e perfumes. Tais produtos também serão excluídos dos benefícios quando se trata da circulação de mercadorias nacionais nas ALCs. Contudo, a legislação é bastante detalhada e, mesmo nos grupos de produtos citados, existem exceções. Por exemplo, apesar de automóveis de passageiros não receberem benefícios, veículos que servem como ambulâncias são contemplados pelas vantagens da ALCBE5.

Os produtos nacionais ou nacionalizados são isentos de IPI. Observa-se, a partir do texto da lei, que os produtos estrangeiros e nacionais possuem condições de competitividade (pelo menos no que tange aos incentivos fiscais) muito parecidas no interior das ALCs. Entretanto, há um predomínio de produtos nacionais nas prateleiras dos supermercados e em outros estabelecimentos em Brasiléia e Epitaciolândia. Isto se explica pela ausência de regulamentação da ALCBE, que demonstra que o regime aduaneiro não saiu do papel, de modo que as empresas cadastradas na SUFRAMA, na maioria dos casos, nunca fizeram uma importação por meio do regime, tendo sido beneficiadas apenas com os incentivos fiscais, principalmente de IPI e ICMS, oriundos de compras nacionais (SENHORAS, 2013, p.11). A ausência de efetividade também encontra explicação na existência da zona de livre comércio altamente dinâmica e atrativa de Cobija, que compete no espaço regional com as cidades de Brasileia e Epitaciolândia.

Elói Martins Senhoras (2013) identificou dois padrões distintos na evolução das ALCs que são construídos não somente pela regulamentação ou não das mesmas como também pelo porte das cidades que as recebem, como mostra o Quadro 5 a seguir:
5 No caso de veículos nacionais. Para veículos internacionais que servem de ambulância, faz-se necessária a regulamentação plena da Área de Livre Comércio, para que os mesmos possam ser adquiridos com as vantagens previstas na lei 8.857 .

6 A posição ideal é no anel exterior à conturbação Brasileia/Epitaciolândia, junto ao eixo rodoviário que liga a conurbação a Rio Branco. Nessa posição, as cargas dos veículos seriam vistoriadas antes mesmo das mercadorias entrarem na cidade de Brasileia.

Quadro 5. Operação das Áreas de Livre Comércio-ALCs

\begin{tabular}{|c|c|c|c|c|c|}
\hline UF & ALC & $\begin{array}{c}\text { ALC } \\
\text { Regulamentada }\end{array}$ & $\begin{array}{c}\text { Empresas } \\
\text { Cadastradas na } \\
\text { Suframa }\end{array}$ & $\begin{array}{c}\text { Empresas aptas } \\
\text { para receberem } \\
\text { o benefício } \\
\text { fiscal }\end{array}$ & $\begin{array}{c}\text { Volume de } \\
\text { Importações } \\
\text { em US\$ }\end{array}$ \\
\hline AM & Tabatinga & Sim & 181 & 72 & $509.961,38$ \\
\hline RO & Guajará-Mirim & Sim & 1081 & 372 & $2.906 .876,51$ \\
\hline RR & Boa Vista & Sim & 3450 & 1680 & $2.978 .566,42$ \\
\hline RR & Bonfim & Não & 30 & 08 & 0 \\
\hline AP & Macapá-Santana & Sim & Não Informado & Não Informado & $28.198 .907,99$ \\
\hline AC & Brasileia- & Não & 491 & 159 & 0 \\
\hline AC & Cruzeiro do Sul & Não & 503 & 292 & 0 \\
\hline
\end{tabular}

Fonte: Senhoras, 2013.

A partir do texto da lei, fica estipulado que a ALCBE está sob a administração da SUFRAMA, que fica responsável por autorizar e controlar as importações e internamentos de mercadorias em Brasiléia e Epitaciolândia. O escritório da SUFRAMA em Brasiléia se encontrava em posição inadequada para o exercício das suas responsabilidades, ${ }^{6}$ estando situado (até janeiro de 2015) na área central de Brasileia, na rua Geni Assis. Os problemas detectados pela ALCBE implicam no não alcance dos objetivos desejados. Contudo, podem ainda causar um mal maior: a geração de empregos do outro lado da fronteira e o 
vazamento da renda nacional. Há de se destacar que a situação em um curto prazo pode se modificar. Atualmente, há uma forte pressão de autoridades políticas acreanas e grandes empreendedores para que o texto da lei 8.857 possa passar a valer integralmente, permitindo que os comerciantes de Brasiléia e Epitaciolândia possam importar com vantagens fiscais, fato que modificaria sensivelmente as relações entre as cidades brasileiras e Cobija, exigindo uma reavaliação de algumas das premissas deste artigo, sobretudo aquelas que dialogam frontalmente com o arranjo econômico das relações entre as cidades estudadas. Isso ocorreria porque Brasiléia e Epitaciolândia poderiam ser inundadas de mercadorias estrangeiras a preços mais competitivos, afetando diretamente a Zona Franca de Cobija.

A morosidade na implementação de todos os termos da ALCBE levantam questionamentos que nos levam a especulações: uma primeira hipótese explicativa para a morosidade seria a benevolência em relação a Cobija, visto que a manobra brasileira de liberação do imposto de importação poderia impactar dramática e negativamente o espaço conurbado vizinho. A segunda hipótese é centrada na característica econômica que se deseja para a conurbação Brasiléia e Epitaciolândia, afinal, as atuais políticas fazem com que o espaço urbano seja moldado de forma que as cidades ganhem aspecto de um centro regional de distribuição de mercadorias produzidas em todo o Brasil a preços competitivos. A liberação do imposto de importação poderia fazer com que essa característica fosse substituída paulatinamente pela presença de centros de distribuição de produtos estrangeiros, o que impactaria negativamente nas atividades dos produtores nacionais.

\section{Políticas territoriais de fronteira bolivianas}

A Bolívia possui 15 zonas francas instaladas em seu território, sendo que as mesmas possuem regulamentação distinta. Existem zonas francas de incentivo comercial, industrial e ambos uma parcela dessas zonas francas situa-se junto aos limites internacionais, como é o caso das cidades gêmeas de Cobija, junto ao Brasil, e Desaguadero, junto ao Peru. $O$ grande número de zonas francas na Bolívia evidencia a importância dessa estratégia como elemento de gestão territorial do país.

Zona Franca é a área estabelecida dentro do território nacional onde se pode introduzir - temporariamente -, à espera de um destino posterior, mercadorias nacionais ou estrangeiras sem submetê-las ao pagamento de impostos aduaneiros. O objetivo do regime é a geração de empregos sustentáveis e capacitação permanente, a atração de investimentos intensivos principalmente em mão de obra, a captação e desenvolvimento de tecnologia, a geração de valor agregado e o desenvolvimento de uma infraestrutura comercial, industrial e de serviços vinculados ao comércio internacional para a realização de processos produtivos destinados ao mercado interno e fundamentalmente às exportações e à facilitação do comércio7. (BOLíVIA, 2015, Tradução nossa).

O quadro a seguir lista as zonas francas bolivianas, destacando aquelas que se situam junto ao limite territorial do país.
7 Zona Franca área establecida dentro del territorio nacional en la que se puede introducir -temporalmente - mercancías nacionales o extranjeras sin someterlas al pago de tributos aduaneros, en espera de un destino posterior.

El objetivo del régimen es la generación de empleo sostenible y capacitación permanente, la atracción de inversiones principalmente intensivas en mano de obra, la captación y desarrollo de tecnología, la generación de valor agregado y el desarrollo de una infraestructura comercial, industrial y de servicios vinculados

al comercio internacional para la realización de procesos productivos destinados al mercado interno y fundamentalmente a las exportaciones y la facilitación del comercio. (BOLÍVIA, 2015). 
Quadro 12. Zonas Francas Bolivianas

\begin{tabular}{|c|c|c|c|}
\hline Zona Franca & Departamento & Tipo & $\begin{array}{c}\text { Situa-se junto } \\
\text { ao limite } \\
\text { internacional }\end{array}$ \\
\hline Desaguadero & La Paz & Comercial & Sim \\
\hline La Paz Comercial & La Paz & Comercial & Não \\
\hline Zona Franca Industrial GIT La Paz & La Paz & Industrial & Não \\
\hline Zona Franca de Patacamaya & La Paz & Industrial & Não \\
\hline Cochabamba & Cochabamba & Comercial e Industrial & Não \\
\hline Puerto Aguirre & Santa Cruz & Comercial & Sim \\
\hline Puerto Suarez & Santa Cruz & Comercial e Industrial & Sim \\
\hline Santa Cruz Winner & Santa Cruz & Comercial e Industrial & Não \\
\hline Santa Cruz Warnes & Santa Cruz & Comercial e Industrial & Não \\
\hline Zona Franca de San Matías & Santa Cruz & Comercial & Sim \\
\hline Oruro & Oruro & Comercial e Industrial & Não \\
\hline Villazón & Potosi & Comercial & Não \\
\hline Yacuiba & Tarija & Comercial & Não \\
\hline Guayaramirim & Beni & Comercial & Sim \\
\hline Cobija & Pando & Comercial e Industrial & Sim \\
\hline
\end{tabular}

Fonte: BOLÍVIA, 2015, organizado pelo autor.

As aglomerações urbanas de Puerto Aguirre, Puerto Suarez, San Matías, Guayaramirim e Cobija, que são contempladas pelo regime da Zona Franca, situam-se junto ao limite com o Brasil. O desenvolvimento econômico das áreas lindeiras, que já é uma estratégia importante para a maioria dos países, parece ser uma das políticas prioritárias da gestão do território boliviano, fato que encontra explicação no seu doloroso histórico de subtrações territoriais que é contado desde a formação do mesmo como um Estado Nacional, o fraco desenvolvimento industrial relativo (frente aos seus vizinhos) e a posição fortemente soberanista de sua política exterior, acentuada com a ascensão de Evo Morales ao poder.

\section{Zona Franca de Cobija}

Os primeiros benefícios fiscais concedidos a Cobija, capital do Departamento de Pando, datam de setembro de 1965. Desde então, a legislação se modificou várias vezes até chegar ao atual formato. A Zona Franca de Cobija propriamente dita foi criada em 1983, sendo a primeira experiência deste tipo no território boliviano (MACHADO, RIBEIRO E MONTEIRO, 2014). Os benefícios da Zona Franca se estendem às atividades industriais e comerciais, válidos para a área urbana de Cobija. Em 2012, cerca de 110 milhões de dólares entraram na área da Zona Franca, sendo que a taxa de crescimento anual oscila de 10\% a 15\% (LA ZONA FRANCA...,2013). Em 2011, 49\% das mercadorias que foram importadas pela Zona Franca vieram do Chile. No mesmo ano, cerca de 34\% vieram do Brasil e $11 \%$ dos Estados Unidos. Recentemente, as importações diretas da China tem registrado aumento (LA ZONA FRANCA...,2013). 
Na Zona Franca de Cobija, os importadores só pagam 1,5\% pela internação das mercadorias, sendo que estes recursos são transferidos ao Tesouro Geral da Nação-TGN. Contudo, todas as mercadorias que são vendidas em Cobija deverão gerar notas fiscais, sendo que o lucro do vendedor é passível de ser tributado (LA ZONA FRANCA...,2013). Por esse motivo pode-se ver na paisagem urbana alguns estabelecimentos fechados por motivos fiscais. A existência de estabelecimentos fechados em diversos pontos da cidade sugere a atuação de uma fiscalização efetiva.

Em 2006 encontravam-se instaladas em Cobija 208 empresas, sendo que, deste montante, somente $10 \%$ pertenciam a estrangeiros (MACHADO; RIBEIRO; MONTEIRO, 2014). Estima-se que na Zona Franca de Cobija cerca de 90\% dos compradores sejam brasileiros (LA ZONA FRANCA...,2013). Nesse sentido, a variação cambial no Brasil pode impactar dramaticamente nas suas vendas. Como foi abordado, com a alta do dólar registrada no período 2014/2016, a participação de brasileiros diminuiu nas vendas de Cobija, pois o produto internado na Zona Franca perde a competitividade. Por outro lado, um cenário contrário (de queda do dólar) tende a estimular a compra de brasileiros em Cobija, pois o produto vendido no comércio da Zona Franca ganhará competitividade.

Nem todas as empresas de Cobija são usuárias da regulamentação da Zona Franca. Em dezembro de 2011, estavam registrados 153 usuários, sendo que $15 \%$ destes se encontravam inativos (se registraram somente para efetuar uma ou poucas importações) (CARLO, 2013).

Figura 2. Aspecto da Zona Franca de Cobija - Calle Enrique Fernandez Cornejo

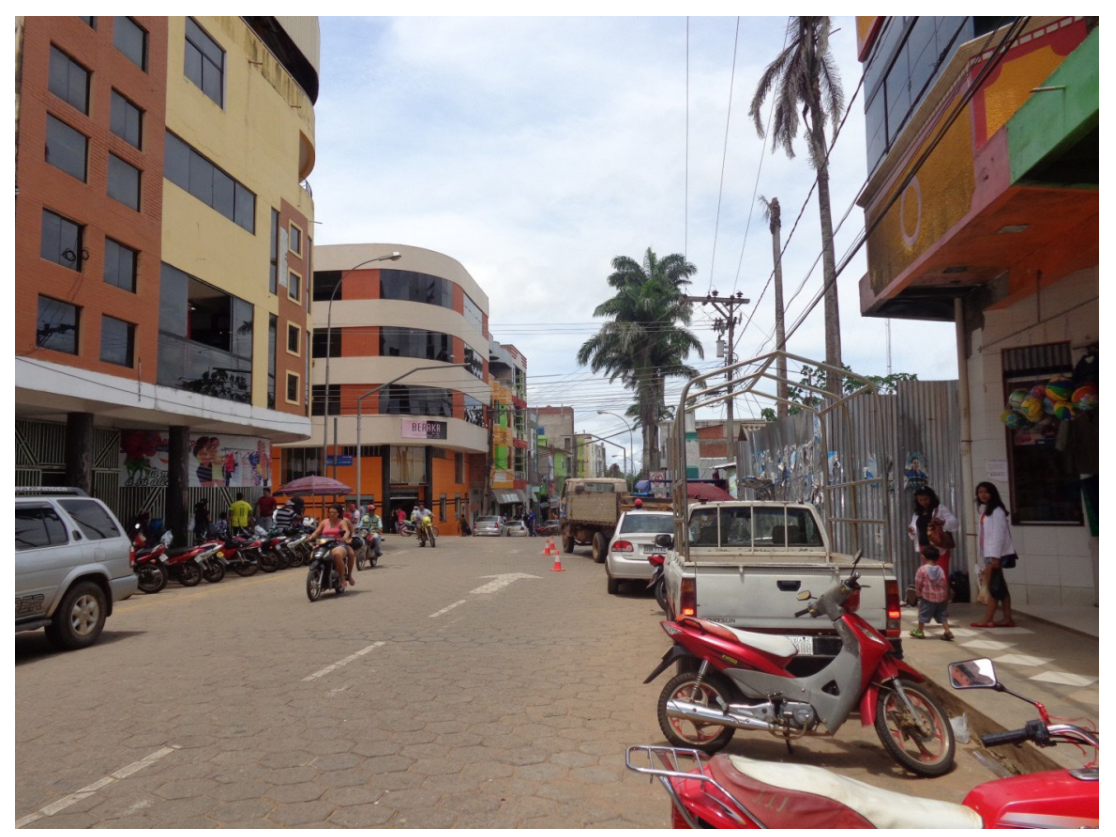

Fonte: Foto do autor. 


\section{Alguns efeitos das políticas territoriais nas cidades de Brasileia e Epitaciolândia}

As políticas territoriais provocam muitos efeitos na realidade geográfica das cidades estudadas. Alguns desses efeitos estão encadeados e são de difícil mensuração. No caso das cidades brasileiras, torna-se notório o caráter exportador dos municípios, advindo da capacidade dos mesmos de internar mercadorias (produzidas em diversas partes do Brasil com certas vantagens fiscais). O mesmo não pode ser dito pela importação, que possui registros modestos, o que é explicado pelo fato do dispositivo de importação com vantagens fiscais ainda não estar em vigência. A Tabela 1 a seguir apresenta os dados de exportação e importação dos principais municípios acreanos.

Tabela 1. Exportações e Importações de Brasileia, Epitaciolândia e Rio Branco expressas em dólar no ano de 2012

\begin{tabular}{|c|c|c|c|}
\hline Município & Exportação & Importação & Saldo \\
\hline Brasileia & 4.185 .040 & 185.750 & 3.999 .290 \\
\hline Epitaciolândia & 4.044 .704 & 284.931 & 3.759 .773 \\
\hline Rio Branco & 3.583 .455 & 4.114 .974 & -531.519 \\
\hline Total do estado & 11.813 .199 & 4.592 .780 & 7.220 .419 \\
\hline
\end{tabular}

Fonte: ACRE, 2013

A vocação comercial das cidades foi potencializada com a política territorial, fazendo com que as principais avenidas das cidades em questão se tornassem centros varejistas e atacadistas mais dinâmicos do que o porte das cidades estudadas poderia sugerir. O estabelecimento comercial "Conquista", especializado em materiais de construção produzidos em diferentes pontos do território brasileiro, aproveitase das vantagens fiscais para internar mercadorias a partir das regras estabelecidas pela ALCBE e fiscalizadas pela SUFRAMA, constituindo-se em um importante centro regional de distribuição de mercadorias.

Figura 3. Fachada do estabelecimento comercial Conquista, situado na Avenida Coronel Marinho Monte, em Brasileia/AC

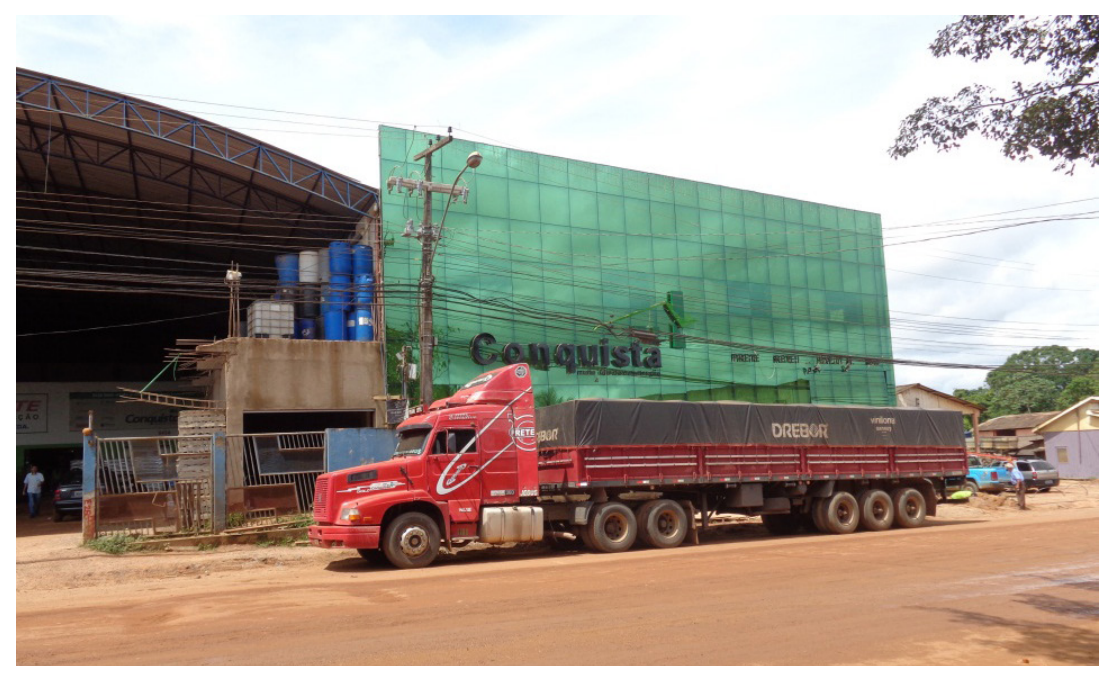

Fonte: Foto do autor 
O caráter de "terras de oportunidades" dado aos dois municípios acreanos acaba encontrando síntese no seu cosmopolitismo demográfico. Em investigações realizadas nas escolas estaduais dos dois municípios, foram levantadas as naturalidades dos estudantes, o que evidenciou a capacidade das cidades em atrair famílias de distintas regiões do Brasil. Dos 3.601 alunos matriculados nas escolas estaduais investigadas, 875 possuem naturalidade externa aos municípios de Brasiléia e Epitaciolândia. A naturalidade externa dos estudantes dos dois municípios está apresentada no Mapa 3. A pulverização das naturalidades dos estudantes dos municípios estudados denunciam, por dedução, a consolidação do status de "terras de oportunidades" que costumeiramente é aplicado aos municípios estudados.

A investigação da rede hoteleira permitiu, por intermédio da consulta às fichas de hospedagem, levantar o local de origem do hóspede e a sua profissão. O local de origem permitiu inferirmos sobre a capacidade de atração das cidades estudadas, o que dialoga com o mesmo fenômeno observado quanto à pulverização de naturalidades nas matrículas das escolas públicas. A profissão do hóspede permite, por sua vez, a inferência sobre a motivação da visita às cidades. Com uma grande concentração de representantes comerciais e empresários, fica evidenciada a importante função comercial desempenhada pelos dois centros urbanos e que foi, por sua vez, amplificada pelas políticas territoriais brasileiras. A crença nessa informação se baseia na observação de padrões: pequenas amostras sobre a profissão de hóspedes podem não possuir significados consistentes; contudo, 89 de 648 hóspedes se declarando representantes de vendas constitui-se como fato relevante e dialoga frontalmente com as funções urbanas das cidades estudadas. Cabe ainda ressaltar que as informações aqui apresentadas, primárias e coletadas diretamente dos estabelecimentos de hospedaria, são muito mais ricas do que as informações subjetivas e generalizadoras oferecidas pelos órgãos públicos das cidades estudadas. Isso se deve à fragilidade das instituições públicas dessas pequenas cidades da periferia territorial brasileira, que, diante das dificuldades citadas, tratam as informações turísticas empiricamente. O Mapa 4 apresenta a origem do hóspede das cidades de Brasiléia e Epitaciolândia (em uma amostra de 1261 hóspedes) e a Tabela 2 a profissão dos hóspedes em um dos hotéis investigados. 
Mapa 3. Naturalidade do estudante da conurbação Brasiléia e Epitaciolândia

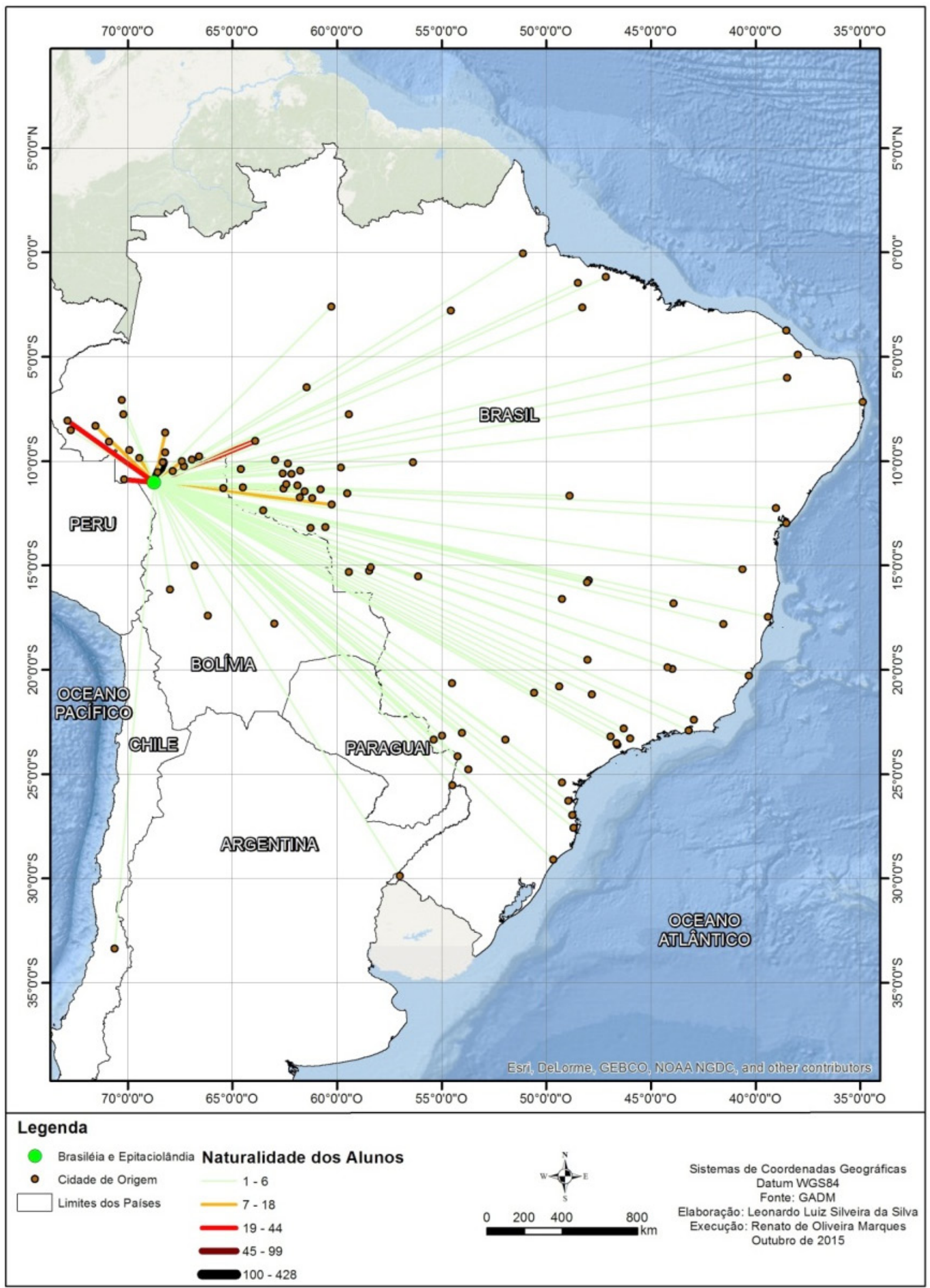


Mapa 4. Local de residência dos hóspedes de hotéis selecionados em Brasiléia e Epitaciolândia em períodos diversificados entre janeiro de 2014 e janeiro de 2015

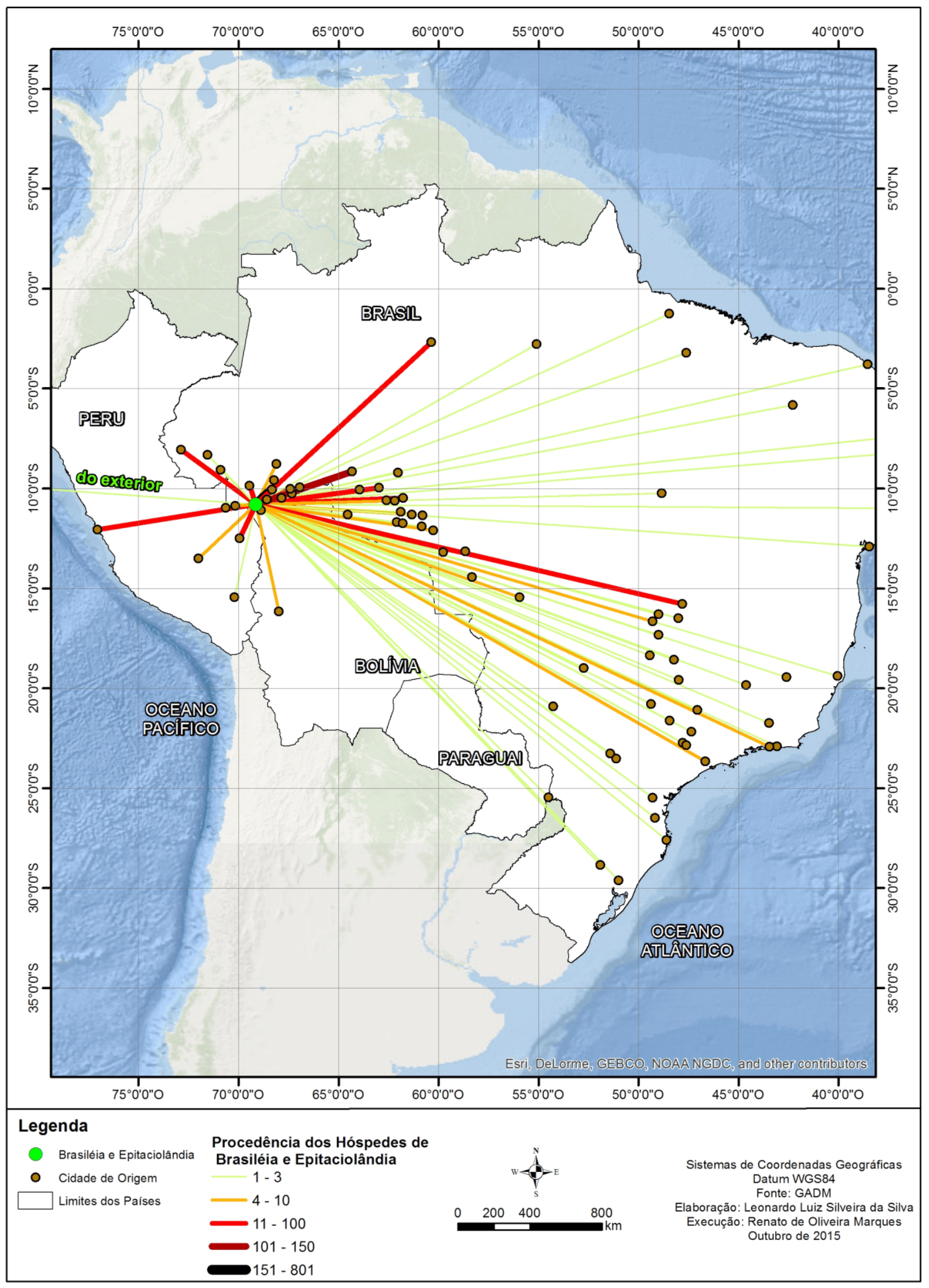


Tabela 2. Profissões dos clientes hospedados no hotel G e K durante o ano de $2014^{8}$

\begin{tabular}{|c|c|}
\hline Profissão do hóspede & Quantidade \\
\hline Funcionário Público & 92 \\
\hline Representante de Vendas & 89 \\
\hline Empresário & 63 \\
\hline Administrador & 51 \\
\hline Advogado & 48 \\
\hline Engenheiro & 39 \\
\hline Professor & 28 \\
\hline Militar & 20 \\
\hline Estudante & 18 \\
\hline Engenheiro Agrônomo & 17 \\
\hline Técnico de Manutenção & 16 \\
\hline Bancário & 15 \\
\hline Economista & 13 \\
\hline Autônomo & 11 \\
\hline Analista de Sistemas & 10 \\
\hline Jornalista & 9 \\
\hline Técnico de Informática & 8 \\
\hline Arquiteto/Urbanista & 8 \\
\hline Médico & 8 \\
\hline Contador & 8 \\
\hline Consultor & 7 \\
\hline Dentista & 6 \\
\hline Outros & 64 \\
\hline Total & 648 \\
\hline
\end{tabular}

Fonte: Levantamento das fichas cadastrais dos hóspedes junto à administração do hotel realizado pelo autor.

\section{Alguns efeitos das políticas territoriais na cidade de Cobija}

É importante ter em mente que a cidade de Cobija apresentase, frente às suas cidades vizinhas acreanas, de forma assimétrica. Tal assimetria não se manifesta somente pela questão demográfica (Cobija é um pouco mais populosa do que as duas cidades acreanas juntas), mas também pelo seu status político: a cidade boliviana em questão é capital departamental. Além disso, Cobija é agraciada com uma Zona Franca, que, diferentemente do que acontece com as cidades brasileiras estudadas, permite que os seus cidadãos realizem importações com incentivos fiscais. Como já foi dito, há uma estimativa de que clientes brasileiros sejam responsáveis por 90\% das compras no comércio de Cobija, situação que pode oscilar ao sabor das mudanças cambiais.
8 Somente os hóspedes que preencheram o campo "profissão" na ficha cadastral. Muitos hóspedes não preenchem tal campo. 
A cidade de Cobija possui duas zonas comerciais antagônicas: de um lado, a zona marcada pela presença de produtos importados oferecidos a preços atraentes aos clientes brasileiros e à estreita classe local economicamente mais favorecida; de outro lado, um comércio baseado em produtos locais e de uso cotidiano, tais como os de roupas, limpeza e alimentício. A assimetria abrupta entre estas duas zonas ilustra com impressionante nitidez aquilo que Milton Santos (2004) denunciou na virada da década de 1970 para os anos 1980: a existência de dois circuitos econômicos nas cidades dos países subdesenvolvidos. Milton Santos não faz referência específica às cidades que são assistidas por políticas territoriais. O seu modelo tenta servir as cidades dos países do mundo subdesenvolvido. Contudo, as políticas territoriais de Cobija fizeram com que a paisagem urbana explicitasse de maneira notória o modelo teórico.

O dinamismo econômico possibilitado pela Zona Franca trouxe, a reboque, uma outra função que nele se apoia: a educacional. A proliferação de cursos superiores em Cobija é muito mais expressiva do que o porte da cidade poderia sugerir. O comércio deu a força econômica necessária para que a cidade desenvolvesse um importante sistema educacional de ensino superior que conta com um número significativo de estudantes brasileiros, matriculados, sobretudo, no curso de medicina.

A investigação da rede hoteleira em Cobija permitiu, assim como nas cidades de Brasiléia e Epitaciolândia, visualizarmos a capacidade de atração e a motivação da hospedagem por intermédio das profissões. A atração esta evidenciada no Mapa 5 e as profissões dos hóspedes estão apresentadas na Tabela 3.

Figura 4. Núcleo de pós-graduação da Universidade Amazônica de Pando-UAP, posicionado em área externa ao campus, no centro de Cobija

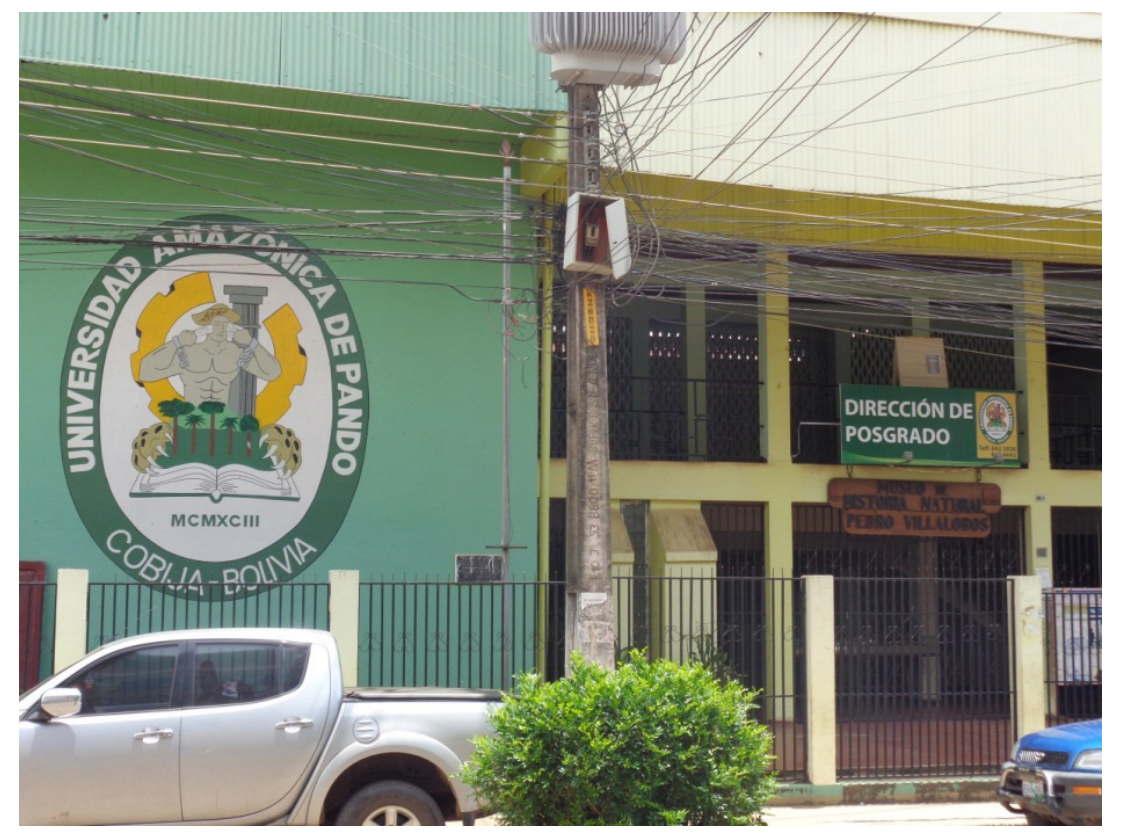

Fonte: Foto do autor 
Mapa 5. Local de residência dos hóspedes de hotéis selecionados em Cobija em períodos diversificados entre janeiro de 2014 e janeiro de 2015

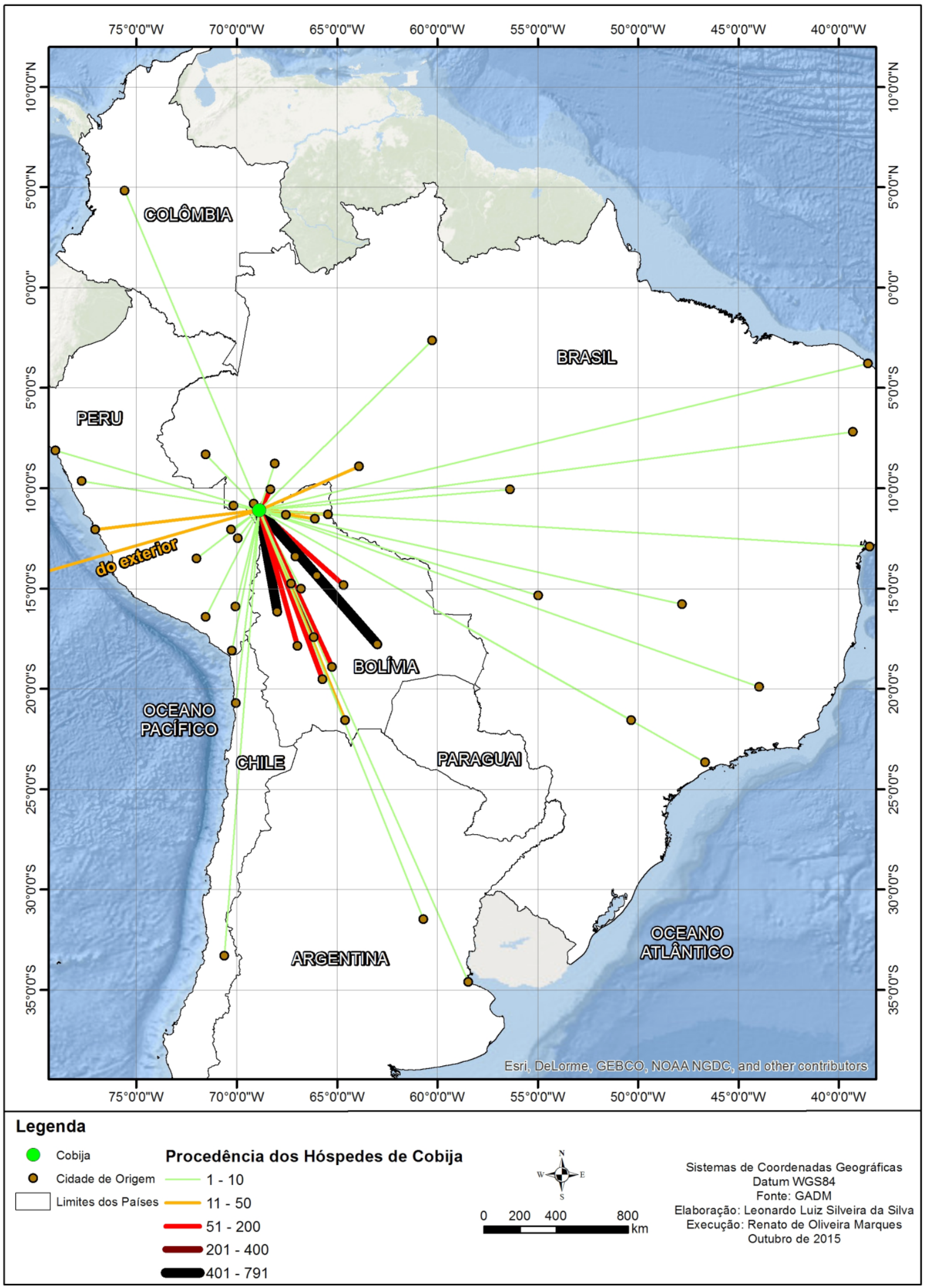


Tabela 3. Profissão dos hóspedes do hotel El Cristo: Amostra de $26 / 6 / 2014$ a $10 / 10 / 2014$

\begin{tabular}{|c|c|}
\hline Profissão do hóspede & Quantidade \\
\hline Estudante & 109 \\
\hline Engenheiro & 50 \\
\hline Advogado & 29 \\
\hline Funcionário Público & 28 \\
\hline Comerciante & 21 \\
\hline Jogador de futebol & 18 \\
\hline Médico & 14 \\
\hline Cineasta & 13 \\
\hline Mecânico & 11 \\
\hline Administrador & 10 \\
\hline Contador & 9 \\
\hline Representante de medicamentos & 8 \\
\hline Empresário & 7 \\
\hline Motorista & 5 \\
\hline Auditor Fiscal & 4 \\
\hline Engenheiro Agrônomo & 4 \\
\hline Psicólogo & 4 \\
\hline Pastor & 3 \\
\hline Professor & 2 \\
\hline Outras & 17 \\
\hline Total & 366 \\
\hline
\end{tabular}

Fonte: Levantamento das fichas cadastrais dos hóspedes junto à administração do hotel realizado pelo autor.

Fica evidenciado o rótulo de cidade universitária dado a Cobija, o que alude a uma de suas principais funções urbanas. A função administrativa, consolidada pela seu status de capital departamental dialoga com a quantidade expressiva de funcionários públicos identificados nesta pesquisa. Destacam-se ainda, conjuntamente, representantes de medicamentos, comerciantes, contadores e administradores, que ajudam a expressar a função comercial da cidade.

\section{Considerações Finais}

As faixas de fronteiras são áreas estratégicas tanto para o âmbito da cooperação quanto para o da segurança. As cidades que nela estão inseridas acabam sendo espaços ainda mais sensíveis pela capacidade das mesmas em articular e dispersar fluxos, constituindose como verdadeiros nós de diversas redes transnacionais. As cidades gêmeas, em particular, são ainda mais estratégicas por serem pontos preferenciais da comunicação das redes transnacionais e articularem, de forma legal e ilegal, diversos fluxos que penetram no espaço nacional (ainda que os circuitos ilegais, provavelmente, igualmente sensíveis às políticas territoriais, serem de difícil mensuração). 
Figura 5. Cena do comércio paralelo praticado por bolivianos em Brasileia/AC

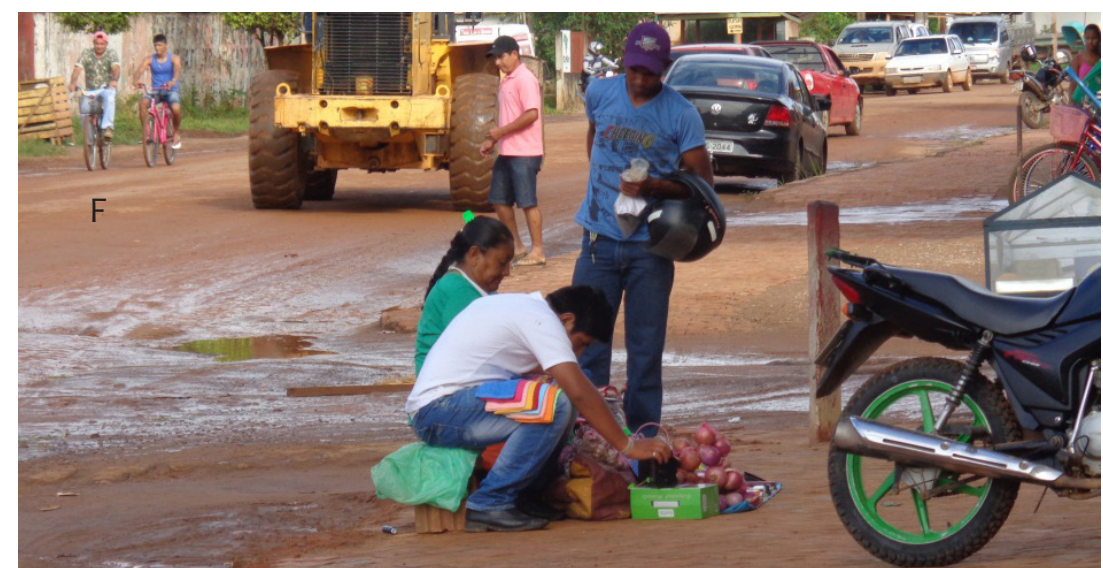

Fonte: Foto do autor

Sendo assim, torna-se uma política comum dos países estudados privilegiarem a faixa de fronteira e as cidades nela inseridas como forma de promover um desenvolvimento anômalo, capaz de fazer jus à posição estratégica. Como uma via compensatória às políticas empregadas pelos Estados, o desenvolvimento econômico das cidades de fronteira auxilia a territorialização da periferia territorial dos países que as abrigam.

O estudo de caso em voga neste artigo centrou-se em cidades gêmeas amazônicas, dotadas de fluxos menos importantes do que em outros trechos do território do Brasil e da Bolívia (Corumbá-Brasil e Porto Quijarro-Bolívia, por exemplo, articulam fluxos mais intensos). Ainda assim, Brasiléia, Epitaciolândia e Cobija recebem incentivos via políticas territoriais que são capazes de modificar a sua realidade geográfica. Tais cidades apresentam dinamismo econômico e migratório muito acima do que o seu porte poderia sugerir. A renúncia fiscal dos governos do Brasil e da Bolívia, ainda que parcial, visa notoriamente a fortalecer o espaço de fronteira, tornando o descompasso entre o porte das cidades e o seu dinamismo uma expressão de sua peculiaridade regional.

Destacam-se, nas cidades brasileiras, grandes empreendimentos comerciais, ainda que a indústria seja incipiente e que as vantagens fiscais não incluam facilidades para a importação. Especializada na importação de produtos estrangeiros e possuindo equipamentos educacionais muito desenvolvidos, Cobija torna-se um destino desejado por estudantes e por consumidores de produtos estrangeiros de diversos padrões. A combinação de políticas territoriais especiais e políticas de cooperação bem estabelecidas (como a possibilidade de brasileiros estudarem em Cobija) fazem com que a disposição dos fluxos regionais encontre nas cidades estudadas nós que os articulam, modificando a realidade geográfica em nome de sua posição estratégica.

\section{Referências}

ABINZANO, R. C. Las regiones de frontera: espacios complejos de la resistência global. In: OLIVEIRA, T.C.M de (org.). Territórios sem limites: estudos sobre fronteiras. Campo Grande: UFMS, 113-130 p. 
O papel das políticas territoriais especiais para a transformação das cidades de zona de fronteira: o caso das cidades gêmeas de Brasileia, Epitaciolândia e Cobija

ACRE, Acre em números, Secretaria de Estado e Planejamento (SEPLAN), Departamento de estudos e pesquisas (DEP), 2013. Disponível em http:// www.ac.gov.br/wps/wcm/connect/eoc7fdoo42426ebeg196b371c3a11451/ Acre\% 2 B Em\%2 B N u \% CC \% 81 meros\% 2 B $2013+$ web + editado. pdf?MOD=AJPERES\&CONVERT_TO=urI\&CACHEID=eoc7fdoo $42426 \mathrm{ebe}$ 9196b371c3a11451

AMIN, A. Spatialites of globalization. Environment and Planning A, London, Vol. 34, pag. 385 - 399, 2002.

BADIE, B. Um mundo sem soberania: os Estados entre o artifício e a responsabilidade. Lisboa: Instituto Piaget, 1999, 326 p.

BADIE, Bertrand. O fim dos territórios: Ensaio sobre a desordem internacional e sobre a utilidade social do respeito. Lisboa: Instituto Piaget, 1995, $304 \mathrm{p}$.

BOLIVIA. Embajada del Bolivia em Brasil. Directorio de zonas francas. Disponível em http://www.embolivia.org.br/nota.php?idn=43. Acesso em 18 de julho de 2015.

BRASIL, Constituição Federal. Lei 8.857 de 8 de Março de 1994. Brasília: 1994, Disponível em: http://www.planalto.gov.br/ccivil_03/ Leis/1989_1994/L8857.htm

BRASIL. Ministério da Integração Nacional/Secretaria de Programas Regionais/ Programa de Desenvolvimento da Faixa de Fronteira. Proposta de Reestruturação do Programa de Desenvolvimento da Faixa de Fronteira. Brasília: Ministério da Integração Nacional, 2005.

BRASIL. Ministério da Integração Nacional/Secretaria de Programas Regionais/ Programa de Desenvolvimento da Faixa de Fronteira. Faixa de Fronteira: Programa de Desenvolvimento da Faixa de Fronteira. Brasília: Ministério da Integração Nacional, 2009.

CARLO, C. Grupos econômicos em el comercio de importaciones: Cobija, migración y zona franca. Tinkazos, La Paz, número 33, 2013, p.47-66.

COELHO, K. N. B. O planejamento urbano regional e a sua importância para as cidades de fronteira. In: XV ENANPUR Encontro Nacional da Associação Nacional de Pós-graduação e Pesquisa em Planejamento Urbano e Regional. 2013, Recife, Anais..., 2013, v. XV, p.1-12.

HISSA, C. E. V. A mobilidade das fronteiras. Belo Horizonte: Editora UFMG, 2002.

LA ZONA FRANCA en el norte genera al menos \$US 110 MM. La Razón, La paz, 12 de Mayo de 2013. Disponível em: http://www.la-razon. com/suplementos/financiero/Zona-Franca-norte-genera-MM_o_183 0417048.html. Acesso em: 18 de jul. 2015. 
MACHADO, V. G.; NETO, P. M. R. Presos estrangeiros no Brasil e o problema da seletividade penal. Derecho y Cambio social, Lima, edição de 2014. Disponível em: $\quad$ http://webcache.googleusercontent.com/search?q=cache:W-W Ud8e8kVYJ:www.derechoycambiosocial.com/revista035/PRESOS ESTRANGEIROS_NO_BRASIL_E_O_PROBLEMA_DA_SELETIVIDADE_ PENAL.pdf $+\& c d=1 \& h l=p t-B R \& c t=c l n k \& g l=b r>$. Acesso em: 14 dez. 2015.

MACHADO, L. O. Limites, Fronteiras e Redes. In: STROHAECKER, Tania Marques, et. ali. Fronteiras e espaço Global. Porto Alegre: Associação dos Geógrafos Brasileiros, 1998.

. Limites e Fronteiras: da alta diplomacia aos circuitos da ilegalidade. Revista Território, Rio de Janeiro, ano V, n8, p.7-23, jan./jul., 2000.

MACHADO, L. O. et.al. O desenvolvimento da faixa de fronteira: uma proposta conceitual-metodológica. In: OLIVEIRA, T.C.M. de (Org.). Território sem limites: estudo sobre as fronteiras. Campo Grande: UFMS, 2005, 87-112.

MATTOS, C. M. Geopolítica e Teoria de Fronteiras. Rio de Janeiro: Biblioteca do Exército, 1990.

SANTOS, M. O espaço dividido. São Paulo: Edusp, 2ªd., 2004.

SENHORAS, E. M. Regionalização Internacional e a inserção brasileira de micro áreas de livre comércio. VI Jornadas de la Asociación Latinoamericana de Relaciones Internacionales, Santiago, jul. 2013, p.1-15.

SUFRAMA, Áreas de Livre Comércio, Manaus. Disponível em: http:// www.suframa.gov.br/invest/zona-franca-de-manaus-alc.cfm Acesso em: 17 de jul. 2015.

TERENCIANI, C. Interculturalidade e "Cidades-Gêmeas": ¿novas configurações identitárias? En Contribuciones a las Ciencias Sociales, Febrero 2012, www.eumed.net/rev/cccss/18/

Leonardo Luiz Silveira da Silva. Doutor em Geografia pela PUC-MG, professor de Geografia do Colégio Magnum Agostiniano, Rua Paulo Piedade Campos, $n^{\circ} 730$, apto 202 A, bairro Estoril, Belo Horizonte, Minas Gerais. CEP 30494060. E-mail: leonardosilva@magnum.com.br. 